\title{
Schools, Students, Computers and Curriculum in Victoria in the 1970s and 1980s
}

\author{
Arthur Tatnall \\ Victoria University, Melbourne, Australia \\ Arthur.Tatnallevu.edu.au
}

\begin{abstract}
Although computers today are commonplace and are widely used at all levels of education, prior to the mid-1970s the idea of introducing school students to the use of computers, or of a school owning its own computer was difficult to imagine. This chapter tells the story of the introduction of computers into schools in Victoria, Australia in the 1970s and 1980s. It begins by looking at school computing before the PC and then goes on to describe the use of computers at Watsonia High School where I was teaching at the time. I describe my involvement and experiences with computers in schools in this exciting period, in particular looking at computing curricula: Computers in Society and Computer Science at Watsonia High. The chapter also tells of the Commonwealth Computer Education Program and the various support structures that were put in place to assist schools. It consists of a reflection on my own experiences of school computing during this period.
\end{abstract}

Keywords: Schools, Curriculum, Australia, Computers in Society, Computer Awareness, Computer Science, Apple][, Australian Educational Computer, Computer Education Support Structures.

\section{Beginnings of an Interest in Computing}

In this chapter I describe my involvement with computers in Victorian schools in the period of the 1970s-1980s. I provide some vivid reflections on my experiences at this time both as a teacher and as an educational consultant.

From my earliest memories at school I recall being interested in the sciences, both physical and biological. I soon also developed an interest in robotics and was fascinated by the idea of the computer or 'electronic brain' as it was then often called. I had no opportunity to do anything with a computer though until at Melbourne University in $3^{\text {rd }}$ year physics we had a unit on FORTRAN IV programming. We entered our programs on punch cards at the university and then the packs of cards were sent off to an IBM mainframe in St Kilda for processing. My first FORTRAN program was to print out the first 1,000 prime numbers. My program got to 980 numbers then crashed, I don't know why. Perhaps I had dimensioned one of the variables to 1,000 when it should have been 1,001. I never found out, but I still enjoyed my first experience of programming.

After completing the Science Degree I undertook a Graduate Diploma in Education and then started work as a High School teacher. I had nothing to do with computers 
again for another ten years until the mid-1970s when my colleague Bill Davey arrived at Watsonia High where I was then teaching.

\section{School Computing Before the PC}

Australia moved into electronic digital computing quite early when the CSIR Mk1 (CSIRAC) was built by Trevor Pearcey and Maston Beard for the CSIRO $^{1}$ in the late 1940s [1], but while university computing courses began in the early 1950s, it was quite some time later that it was possible for schools to make any use of computers [2].

It was not until the early 1970s that a few computers started to appear in Australian schools, typically resulting from the exposure of certain teachers to computing during their university studies [3]. In Victoria these early instances included a PDP-8 computer loaned by Digital Equipment to Burwood High School in 1972 [4]. In 1973 an Innovations Grant enabled McKinnon High School to purchase an 8k Wang computer costing over $\$ 10,000$ and because of its high annual maintenance charge (15\% of the purchase price), it was shared with Box Hill High School [4]. These early computers were used almost exclusively by mathematics departments for the teaching of programming and mathematical algorithm design [4]. They had very little impact on other schools in which the idea of owning a computer was unthinkable.

A much larger impact, however, occurred in 1974 with the introduction of the Monash Educational Computer System (MONECS) developed by a group of Computer Scientists at Monash University. MONECS typically ran on a DEC PDP-11 (DEAMON) minicomputer and used mark-sense cards for program and data entry [5]. The students filled in the cards in class at their school using a pencil and then their teacher delivered the cards to a local university for execution. This allowed a class of 30 students to each get two runs in a one-hour period [5] and was designed to teach programming in FORTRAN or BASIC.

In the 1970s and 1980s Victoria had two different types of Secondary Schools High Schools and Technical Schools, and in another development at this time some Victorian Technical Schools experimented with Control Data's PLATO System [6] of computer-assisted instruction for the training of apprentices. The system was, however, very expensive and its use did not proceed.

The arrival of the Apple][ in 1977 saw the end of this period and the beginning of real advances in the use of computers in schools. At around \$2,000 for a 16k Apple][ that used a tape drive (not supplied - you simply used your own cassette recorder) and a television set (also not supplied) as a monitor, the Apple][ was affordable for most schools.

\section{Teaching at Watsonia High School}

I had been teaching Physics, Science and Maths at Watsonia High School (WHS), a school of around 1,000 pupils in the northern suburbs of Melbourne, for five years

\footnotetext{
${ }^{1}$ Commonwealth Scientific and Industrial Research Organisation.
} 
when Bill Davey arrived in 1974. Bill had studied some computing in his Science degree at Monash University and, before coming to Watsonia, had done some computing with one of his maths classes at Bendigo High School using mark sense cards executed at Bendigo Institute of Technology. He had also commenced some tertiary studies in computing and came to Watsonia High keen to do more work in this area.

\section{$4 \quad$ WHS Student Allocation Program at La Trobe University}

In the 1970s in Victoria decisions on curriculum and school organisation were schoolbased (within Education Department guidelines). In the early-1970s Watsonia High decided to organise its junior and middle schools students into 'vertical modular groups' depending on their choice of elective subjects. This meant that, for example, Year 9 and Year 10 students could share the same electives so providing more choice for these students and effectively giving each student an individual timetable. Organising these groups presented quite a challenge when it was done by hand. Someone at the school, however, had found a contact at nearby La Trobe University who had been developing a computer scheduling program that could assist in this task, and in 1974 (and for several years after this) we worked together using La Trobe University's program for student allocation to timetable groups on the university's DEC-10 computer. It worked this way: students filled in a form at school indicating their elective preferences (from a list of possible options) after which Bill and I went to La Trobe University and entered this data using a teletype. The university then ran the program and produced list of possible student groupings which we took back to the school for consideration. Sometimes this process had to be repeated to get useful results, but overall it made this grouping task possible. It also re-introduced me to computing.

\section{Programming in Year 11 Maths at WHS}

In the mid-1970s Bill and I also used the MONECS system at La Trobe University in a Year 11 maths class for teaching BASIC programming so that the students could design algorithms to solve mathematical problems. This work involved the students designing a program (in BASIC) and marking their cards in class using a pencil. Then one of us took the decks of cards to La Trobe to execute the programs. The results were frequently disappointing for the students with the only thing coming back being a print-out listing a number of syntax errors. It typically took most students several tries (with perhaps one or two runs each week) to get their program working. While students today would not persevere with frustrations like this the excitement, at that time, of using a computer and making it do something that you determined meant that they did keep going with it, and indicated that they enjoyed and appreciated the experience. 


\section{The Computer 'Travelling Road Show'}

In this period the Secondary Mathematics Committee (made up of school maths teachers and personal from the Education Department) developed an interest in using computers for mathematics and other aspects of education and a Computer Education Subcommittee (including Bill Davey as one of its members) was formed. The Subcommittee then set up the 'Computer Travelling Road Show' in which groups of two or three of its members would visit schools to promote the use of computers. They normally brought with them a 16k Apple][ (on loan) with cassette tape drive to demonstrate computer applications involving graphics, mathematics, commerce and word processing, rather than just programming, to teachers at curriculum days and school staff meetings $[4,7]$.

\section{Arrival of an Apple][ Computer at Watsonia High}

In 1977 Bill was a member of the Secondary Mathematics Committee and teaching at Watsonia High School. With support from the Committee he put in a curriculum innovations grant submission to the Commonwealth Government to purchase an Apple][ computer for the school. As a result, in 1977 Watsonia High School obtained an Apple][ microcomputer with $16 \mathrm{~Kb}$ RAM and a 110 volt power supply. The school needed to supply a television set (for use as a monitor) and a cassette tape drive as the Apple][ did not come with these as part of the package. This was one of the first Apple][ computers to enter Australian schools. For this year and the next the Apple][ was used mainly for demonstrations and was later upgraded, at considerable expense to the school, to a $64 \mathrm{~Kb}$ machine with a disk drive and mark-sense card reader.

On several occasions I took the computer home to do some work and to show my family. I remember how sensitive the cassette drive was to its volume setting. If this setting was not exactly right the program would not load, or save and it was very easy for our 3 year old son to accidentally knock the volume control. As the Apple][ had no monitor of its own it was necessary to use our home TV set, and when there were problems with the cassette volume setting, loading and saving programs often took much longer than expected, meaning that our son was unable to watch 'Play School' one of his favourite programs.

Bill left Watsonia High at the end of 1978 to take up a new position, leaving me with the Apple][ computer and the decision of what to do with it.

\section{Graduate Diploma in Computer Science}

Seeing a future in educational computing, but conscious of not having a good theoretical background in this area, in 1979 I enrolled in a part-time Graduate Diploma in Computer Science at La Trobe University while still working full-time at Watsonia High. This Graduate Diploma course contained basically all the computing content, but without the other general subjects, of a Bachelor's Degree in Computer Science. Course content included the following components: 
- Programming - in ALGOL (and later Pascal), 6800 assembler, PDP-11 assembler and COBOL

- Software Engineering

- Computer Organisation and Operating Systems

- Information Systems: systems analysis and design and database management, as well as a choice of four of the five ancillary subjects: Introduction to Accounting, Management Accounting, Social Psychology, Numerical Methods and Operations Research.

\section{$9 \quad$ Year 10 'Computers in Society' at Watsonia High}

In 1979 at Watsonia High I introduced a new core subject: 'Computers in Society' into the Year 10 curriculum [8]. At that time Year 10 at WHS had 150 students in five class groups. 'Computers in Society' was a core subject taken by all 150 students for three periods per week throughout the year. The subject consisted of three parts, each of one term's duration and delivered by a teacher who understood and could relate to each particular area [9]. The teaching team consisted of one science teacher (Arthur Tatnall), a commerce teacher and a teacher of social science. Together we determined the requirements for the new subject which consisted of three parts, taught on a round-robin basis each term, with the following units:

- $\quad$ Preliminary Course - Introduction to the Computer (6 periods)

o Introduction to the course. What is a computer? What can it do? What can't it do?

o Demonstration with the Apple][: Apple Vision, Music, Colour Graphics, Space Invaders etc.

o Hands-on experience: instruction in how to operate the Apple][ to run an 'Introductory Program' - printing your own name and address. While each small group of students did this the rest completed an exercise from a text book, then the groups rotated.

o The concept of a computer program - a computer can do only what it is told.

- Introduction to the social implications of computing

- Section A: Structure of the Computer - taught by the Science teacher (3 periods per week for one term)

○ How does a computer work? Block structure of the computer: I/O, memory, CPU, integrated circuits, disk, cassette, printer, number systems and binary code etc.

o Programming: programming languages, flow charts and algorithm design, programming in BASIC using mark-sense cards on the Apple][

o Hands-on experience: graphics, games, uses for student reports, timetables etc.

- Excursion to La Trobe University computer centre 
- Section B: Computers and Business - taught by the Commerce teacher (3 periods per week for one term)

○ Development of uses in business, impact on productivity and employment

o Word Processing: concept, historical development from the manual typewriter, types of word processors, effect on organisation of the office

o Stock Control: comparison of the manual, physical stock control with the latest methods of Point of Sale terminals to highlight changes required of personnel, efficiency and control

o Accounting Systems: comparison of old and new systems to highlight job specifications, productivity, internal communications, payroll, relations with customers. Hands-on experience on the Apple][ and use of marksense cards for a Balance Sheet exercise

o Process Control: production-line, processing industries, effect on quality and productivity

- Information Systems: use of a computer in collating, preparation and presentation of information for things like airline seat reservation, accommodation reservation, vehicle delivery and railway loop control

- Section C: Uses, History and Social Implications of Computer Technology taught by the Social Science teacher (3 periods per week for one term)

○ History of the development of the computer

- Advantages and misconceptions

- Applications: election results, space programme and defence, crime detection, archaeology, traffic control, computer dating (using match maker on the Apple][), computers in home/leisure/entertainment, shopping, medicine, communication

o Implications: privacy, political uses and need for protective legislation, 'Police State', harassment, economic, employment, cashless society (who benefits?) leisure, education, computer crimes, machine controlled society

The course was taken by all 150 Year 10 students using the school's single Apple][ with a mark-sense card reader. This was to be one of the first 'Computer Awareness' courses in Victoria and was offered from 1979 to 1985. (During this period the school purchased another Apple][, making teaching this subject easier) Today it is hard to see how using a single computer and maintaining the students' interest for this course would have been possible, but such was the excitement of having access to the new world of computing, of getting some understanding and experience of using a computer, and of making the computer do something that you determined, that the students did put up with the limited hands-on use that was possible and continued to maintain an interest in the subject despite this. Another factor in the subject's success was the enthusiasm of the teachers involved, who worked to make the subject always interesting and exciting for the students. 


\section{Secondary Computer Education Committee}

The Secondary Computer Education Curriculum Committee was formed in 1980 from members of the Secondary Mathematics Committee, the Board of Inspectors of Secondary Schools, three seconded Computer Education Consultants and a number of practising teachers. I was one of these practicing teachers. The main brief of the committee was the production of Computer Awareness course guidelines and investigation of Computer Science as a discipline. The committee's charter also included publication of computer education articles, collection and propagation of public domain software (for Apple][ and $\mathrm{CP} / \mathrm{M}$ computers) and provision of in-service education for teachers [2].

\subsection{Computer Awareness Guidelines}

In most countries around the world today secondary school students are very aware of information technology and of the many use of computers. This, however, was not the case in the late 1970s and early 1980s when the first microcomputers began to make their appearance in Australian schools [8]. It was also, significantly, the case that few teachers were then aware of how to use a computer, what computers could be used for, or what the implications of their use might be. The solution seen at the time was introduction of 'Computer Awareness' courses.

"Computer awareness is simply the possession of skills and knowledge which enables informed judgements to be made about what is seen or heard about computers. The emphasis in computer awareness courses is on the knowledge and skills which give an appreciation of the capabilities and limitations of computers and their applications rather than on the technical skills required to program or maintain computer systems." [10:1]

Later that year the Secondary Computer Education Committee produced the first edition of its Computer Awareness Guidelines [11]. The Guidelines suggested that this course be offered at Year 10 with the following objectives:

- $\quad$ To reduce bewilderment and fear of the unknown in the minds of individuals and to promote a balanced view of the computer's role in society

- $\quad$ To provide students with sufficient information to enable them to use computer-based services with confidence

- $\quad$ To establish an informed basis for decisions regarding computer applications which have political implications and involve value judgements

- $\quad$ To examine the impact (actual and potential) of the computer on life styles and employment opportunities

- $\quad$ To foster familiarity with computing equipment and, by providing hands-on experience and an introduction to programming techniques, develop, through practical experience, insights into computer processes, uses and limitations

- $\quad$ To provide sufficient understanding about the way in which computers work to comprehend not only what they can do but also what they cannot do 
- $\quad$ To develop an awareness of the potential abuses of computers and computer know-how

- $\quad$ To demonstrate the use of computers in solving problems and to encourage students to apply the principles of problem solving creatively.

The document strongly stressed the interdisciplinary nature of this subject matter and that Computer Awareness should not be equated with Computer Programming [8]. Course content was:

- Section 1: (15\% of available time)

- Historical development of the computer: the abacus, Pascal's adding machine, Babbage's difference engine, generations of electronic computers, the microcomputer

- Structure of a computer: analogue vs. digital computers, input and output, memory, central processing unit, backing store, computer electronics

- $\quad$ Section $2(25 \%)$

- Hands-on experience - booting the system, loading programs, booting the disk operating system, obtaining a catalogue of programs, running programs, switching off the system, creation and use of files, word processing, general computer usage

- Algorithms - the concept of an algorithm, simple flowcharting

- Elementary programming in BASIC, marking cards, program commands, syntax, arithmetical/logical operations, debugging programs

- $\quad$ Section $3(60 \%)$

- Misconceptions about computers - intelligence, infallibility

- Use of computers in government, industry, commerce, science, research, the arts and at home

- Security implications

- Implications of computer use for society: political, economic and social implications.

\section{Year 12 Computer Science}

In 1981 as a result of several years of work by a group of academics, teachers and people involved in various ways with the production and use of computer technology, Computer Science was introduced as a Year 12 Higher School Certificate subject in Victoria [2, 12]. To many, the value of a school subject is measured in terms of its place in the Year 12 (the final year of schooling) curriculum and so as a preparation for tertiary study [3] and this was the case with Computer Science, at least to most students and parents, but not to all teachers.

The original version of course (1981) was made up of a core, optional units and school-based practical work [13]. The core (20 weeks) consisted of: 
- Computer structure

- Algorithms

- Programming languages

- Data structure manipulation (in immediate access memory)

- Input/output devices

- Data processing.

There were four optional units (each of 5 weeks):

A. Social implications of computers

B. Hardware

C. Visits to installations

D. Data processing systems and case studies

of which each school needed to choose two.

Thirdly was school-based practical work.

Initially the core was weighted at $35 \%$ and examined externally, the school assessed options as $30 \%$ and the school-based practical work as $35 \%$ as the subject designers wanted to allow practical work in programming to be given considerable weight [2]. I was a member of the Computer Science Subject Committee from its inception, an Examiner for the first three years and then Chief Examiner until 1991 when the subject was replaced by the Information Technology field of study [14].

Melbourne and Monash universities initially refused to allow the inclusion of Year 12 Computer Science in admission scores for their courses, their stated reasons being that the component of assessment allotted to the formal examination was only $35 \%$ rather than the usual $50 \%[2,15]$ and that the subject did not have sufficient academic merit. The other Victorian universities, however, had no problems with the subject and accepted it fully. When the subject came up for reaccreditation in 1984 [16] the Computer Science Subject Committee, in a compromise designed to satisfy the position taken by Melbourne and Monash universities, recommended that assessment for the subject be changed to: core external examination - 50\%, consensus moderated $^{2}$ practical work - 30\% [17], and school assessed, consensus moderated options $-20 \%$. Changes were also made to the course content, principally to move Social Implications into the core and to change the options. In addition to the consensus moderated practical work, the new course structure [18] consisted of: Core (20 weeks):

\footnotetext{
${ }^{2}$ Consensus moderation was used by several Year 12 subjects as a technique for comparing the work of students in different schools. In Computer Science it was used for both practical work and options. The process involved holding an initial meeting of all teachers of the subject in moderation groups of about twelve at the start of the school year. This meeting would then decide on a common interpretation of the course guidelines. At a final moderation meeting at the end of the school year, a sample of the student work from each school in the group would then be re-examined by the other teachers. If the moderation group as a whole considered that a particular school's work (as judged from the sample) had been marked 5\% (for example) too easily, all the students from that school had their Computer Science option work marks reduced by a commensurate amount. Similarly, the marks from a given school would be increased by the group if this was thought necessary.
} 
- Computer structure and data representation

- The design and implementation of algorithms

- Programming languages

- Data structures

- Input/output devices

- File structures

- System software

- Social implications

There were now two optional units (each of 10 weeks) of which each school had to choose one:

A. Computers in science and engineering

B. Computers in business and government

Melbourne and Monash universities now accepted the subject. Teachers however, were not universally in favour of the new subject [15]. Some claimed that Computer Science was an elitist academic subject, too difficult for some students, and so should not be supported. (It is interesting to note that this was exactly opposite to the view earlier held by Melbourne and Monash universities.) Others noted that the ratio of girls to boys taking Computer Science was almost as low as that for physics, and expressed concern that it was becoming a boys' subject. Perhaps, however, the most damaging criticism came from those teachers who claimed that the presence of a specialist subject detracted from the move to encourage the use of Computers across the Curriculum ${ }^{3}$. An early move in introduction of computers to other subject areas was the use of Apple][ software such as: Lemonade, Hammurabi and the First Fleet (convict) database and Acorn BBC computer software included a word processor, database manager and a role play simulation program called Suburban Fox where students took the role of a fox and learned to survive. A number of the advocates for Computers across the Curriculum saw Computer Science as an adversary and it took some time before these points of view were reconciled. The basis for this view was firstly the claim that the demands made on school computing facilities by Computer Science classes made it difficult for others to obtain adequate access to the machines ${ }^{4}$, and secondly that the existence of a specialist subject would mean that teachers of other subject areas would not bother to include any mention of computing, considering it covered elsewhere. Many of us disputed these claims.

\footnotetext{
${ }^{3}$ In common with several other countries, Computers across the Curriculum was a popular, if ill-defined term in those days. It was generally taken to mean the uncritical promotion of the idea that the computer could enhance learning in all curriculum areas and should be pressed into them with all possible speed.

${ }^{4}$ While containing some truth, this argument misses the point that in most cases the reason that the school had purchased a number of computers at all was to support the teaching of Computer Science. Being a Year 12 subject it was easier to get funds from School Councils and the Education Ministry to buy computers for this purpose than for many other uses.
} 


\section{Year 11 Computer Science at Watsonia High}

In 1981 a new 'Computer Science' subject was introduced at Year 11 at WHS. I intended this subject to follow on from Year 10 'Computers in Society', but also cover much more detail about computing, how computers work, algorithms and programming, while still containing some material on the actual and potential uses of computers and the social implications of their use [19-21]. The subject primarily made use of the school's Apple][ along with use of mark-sense cards at La Trobe University. The subject's content included:

- Computer structure: basic hardware elements and computer structure, data representation, binary numbers, computer logic, coding systems

- Algorithms: concept, modelling, representation with flowcharts, NassiShneiderman diagrams, pseudocode

- Programming fundamentals: top down design, structured programming, testing, errors, debugging, Pascal, BASIC, documentation

- Random numbers and simulations

- Low level programming: machine language, assembly language - Use of LOWLEV [22]

- Operating systems and system software

- Computer applications: databases and data processing, word processing, accounting and finance packages, science and engineering, leisure and education, numerical methods

- Computers and society

- Practical assignments

This subject ran from 1981 at Watsonia High for some years after I left in 1983.

\section{Jacaranda Press Book: Computer Science for Year 11}

In 1983 I was approached by Jacaranda Press (Wiley, Australia) to write a textbook for Year 11 Computer Science [23], and invited Bill Davey to work with me on this. We began to work on a book based on our own school subjects and teaching experiences. We tried to make the book different to the normal textbook of the time and to include student exercises that we had found worked well with our own students. The book was well accepted by schools and quickly became a best seller. It had the following chapters:

1. Introduction to programming through graphics

2. What goes on inside a computer?

3. Data and databases

4. Computers and problem solving

5. Talking to a computer in its own language

6. Computer programming languages

7. Filing, searching and sorting; database programming 
8. Word-processing and communication

9. Number crunching and financial applications

10. Automation and process control - information technology and the future

The book must have made an impression, at least on some students, as even over 30 years later we still get some former students who have kept a copy of the book and would like us to sign it.

\section{Commonwealth Computer Education Program}

By the late 1970s the number of microcomputers in Victorian schools (and those in other Australian states) had begun to grow considerably but without any central direction from education authorities. In 1980 in Victoria to address this issue Anne McDougall was commissioned to report on how computers were then being used in schools and the possibilities for their future use [24].

Constitutionally in Australia it is the State Governments that are responsible for School Education and that determine school curriculum and how it is supported and delivered. In matters of perceived national importance, however, the Commonwealth Government adopts a policy position and supplies funding for specific education projects [25].

Following the rapidly growing interest in the use of computers in education, in February 1983 the Commonwealth Schools Commission expressed the view that:

"The development of a satisfactory program of computer education in Australian schools was of fundamental importance to Australia's future" and "... that the Commonwealth should commit itself to the development of a national computer education (or schools computing) program for all Australian schools, commencing in 1984" [26:1].

In April 1983 the Australian Commonwealth Government then set up the Commonwealth Schools Commission National Advisory Committee on Computers in Schools (NACCS), whose purpose was to provide leadership and funding for Computer Education across all Australian states and territories [25, 26]. NACCS included representatives from the Education Departments of each Australian State and Territory (Queensland, New South Wales, Victoria, Tasmania, South Australia, Western Australia, Australian Capital Territory and Northern Territory), parent organisations, teacher unions, equal opportunity organisations, Catholic Schools, Independent Schools, State School organisations, Universities, the Commonwealth Schools Commission and the Commonwealth Department of Science and Technology [27].

In its report Teaching Learning and Computers in Schools [26] the Committee made comprehensive recommendations covering curriculum development, professional development, support services, software/courseware, hardware and organisation. The report indicated that priorities for curriculum development should be:

- provision of Computer Awareness activities for all students in the early years of secondary schooling

- integration of computing into the school curriculum 
- in-depth (optional) Computer Studies courses at the senior secondary level

- curricula which meet the special needs of relevant disadvantaged groups.

For the period from 1984 to 1986, the Commonwealth Government provided \$19 million in support of the program [3].

NACCS regarded Education Support Services as essential and suggested that appropriate use of funds could include the appointment of education consultants, the further development of comprehensive computer education centres and the provision of grants to support innovative practices in schools [26].

\section{Computer Education Support Structures}

\subsection{Computer Education Consultancy}

In 1981 I was appointed as a Computer Education Consultant. These Consultants were practicing school teachers who were seconded from their schools, usually on a part-time basis, to work from their Regional Education Office. Consultants were subject specialists, chosen for their subject expertise, teaching ability, willingness to adapt to and lead educational change and their ability to get on with and work with other teachers [25]. They were appointed only for a period of twelve months at a time so that they would not lose contact with the school classroom. Unlike most other subject consultants, however, Computer Education Consultants were pioneering a new area of education and had little in the way of established precedent, techniques or materials to assist them. As the use of computers in education was an entirely new area and few teachers had any experience with it the Consultant's task was to introduce and offer suggestions on the use of computers in schools of all types: Primary, Secondary and Technical. Despite working only part-time on this job I typically visited two or three schools each day to discuss matters with individual teachers from a variety of subject areas [28-30], demonstrate software, assist with the configuration of hardware and to conduct whole-school professional development activities.

I remember that after I gave a whole-school demonstration of the use of computers, as part of a professional development activity in a metropolitan primary school, one of the teachers came up to me and said: "But won't some of the kids know more about computers than me". Although we don't always like to admit it, many teachers feel that they must know more than the students about something before they can make use of it or teach it. I suggested an alternative approach of getting one of the more computer-literate students to demonstrate using the computer to the class. This would both be empowering for the student and overcome the teacher's lack of knowledge of computers. I don't know whether she took this advice.

At this time those of us involved in computer education consultancy really attacked the task with 'missionary zeal' believing, rightly or wrongly, that the use of computers in schools could fundamentally change education for the better. I continued in this position in 1982 . 
In 1983 I became a full-time (seconded) General Curriculum Consultant and in 1984 a full-time Computer Education Consultant. This was hard work but very rewarding as our services were highly appreciated by teachers and by schools. We rarely, however, had any interaction with school students, working instead with teachers and school principals.

During this period I also developed several computer programs for Apple][ and MS-DOS, the main ones being LOWLEV (a pseudo assembly language / machine code system), Seasen-PILOT (programming language) and Match-Maker (a student dating program to teach about databases). I also wrote training manuals for Microsoft Works for Windows and for Macintosh.

\subsection{The State Computer Education Centre (SCEC)}

In Victoria, the early development of Computer Education in schools was certainly 'bottom up', beginning with the efforts of a small number of teachers. When the Computer Education 'explosion' began in 1983 the Victorian Education Department saw the need for some form of 'top down' planning and control, and formation of the State Computer Education Centre (SCEC) was the result. After an initial trial in 1984, in 1985 the centre was formalised with a Senior Computer Education Officer, Software Co-ordinator, Professional Development Co-ordinator, Curriculum Co-ordinator, Educational Computer Systems Analyst, and Equal Opportunity Officer all holding deputy-principal positions. seventeen senior-teacher positions (five at SCEC and twelve in the regions), and four assistant teacher positions making up a total staff of twentyseven professional officers [2]. I was appointed to the position of Educational Computer Systems Analyst and continued in this role for the next three years.

SCEC played a significant part in setting the direction of educational computing in Victoria for the next three years by developing policy, producing curriculum documents, evaluating and distributing educational software, evaluating computer systems and producing the 'recommended list' of computer systems for use in schools.

\subsubsection{List of Recommended Computers for Victorian Schools}

The Schools Commission had recommended that computer hardware purchased with program funds "should ... be used to purchase computer hardware which is on the appropriate State Education Department approved list" [31]. As Educational Computer Systems Analyst it was my job to draw up specifications, collect and evaluate submissions and produce this recommended list, which was for computer systems and not just hardware, for all Victorian Government Schools. Apart from providing advice to schools, this recommendation process was necessary to fulfil certain Government contractual and offset ${ }^{5}$ requirements.

5 Victorian Government offsets policy required an investment in Victoria by suppliers, proportional to sales, and noted preference for Victorian manufactured goods, approved decentralised secondary industries, anti-dumping policy and apartheid sanctions against South Africa. 
The 1986 Educational Computing System Specifications [32] document noted that recommended computing systems in schools should offer software, running on the recommended computer hardware, for a substantial number of the following applications:

- Useful tools for teachers and students: word processing, database management systems, spreadsheets, graphic design, expert systems, telecommunications and control technology.

- Problem solving: adventure games, logic games, Logo and Prolog.

- Courseware: simulations, information retrieval systems, data collection and analysis packages, computer controlled experiments, drill and practice and computer aided instruction.

- Programming.

- Vocationally oriented studies.

- Special education.

The document said that these systems should be easy to use, serviceable and ergonomic. They should also be as small be provided at the lowest cost possible. Also, system suppliers should offer upgrades, provide training materials and offer company support to schools and to SCEC. I performed this task for three years before moving to higher education in 1988.

\subsubsection{Designing the Australian Educational Computer}

Such support for the purchase of microcomputers from a State's recommended list was considered to be only an interim measure, necessary only until an Australian Educational Computer could be developed and built. In 1985 two Schools Commission Working Parties were set up to determine 'Educational User Requirements' and 'Educational Technical Requirements'. The idea was then that a 'System Concept Study' and 'Development Proposal' for construction of the computer would follow [15]. The intention was both to develop a high quality computer appropriate for school use but also to provide an opportunity for Australian industry to build the machine. I was appointed as an 'expert' member of the 'Educational Technical Requirements' working party.

In its report [33] the Educational User Requirements working party considered developmental characteristics of school children and learning situations in which computer use was considered appropriate, then attempted to draw up user requirements from each of these. The report gave examples of the learning activities in schools as including: use of computers as a tool in existing subject areas and in Special Education, studying Computer Science, co-operative large group and project group use [27].

Our Educational Technical Requirements working party produced a report [34] containing two main sections:

- The Technical Requirement which gave detailed coverage to: user interface, input/output devices, processing resources, networks, telecommunications and system requirements.

- A section dealing with possible implementations of these requirements to satisfy at least three types of use: 
- Personal

- Classroom

- School-Wide.

The idea was that these uses could be catered for by a family of compatible systems having a common user interface, and that at some stage in the future the way should be left open to connect these systems to computing facilities at the district, regional, state or national levels [27].

This, however, was all before the days of the ascendancy of the IBM-PC, MSMOS and the Apple Macintosh and schools made use of a large variety of computers including the Apple][, BBC (Acorn), Tandy TRS-80, Commodore Vic20, Commodore 64, Microbee, (an Australian designed computer) and the CP/M machines: Cromenco and Micromation. When the Computer Education Program funding ended in 1987 the idea of the Australian Educational Computer was not taken up by the Department of Science and Technology and so was dropped. In retrospect this was probably a good thing as it was not long before the PC and Macintosh had, between them, captured almost all the school market and our new computer would have stood a good chance of becoming an expensive white elephant [27].

\subsection{The Australian Computer Society (ACS)}

The ACS was always supportive of school computing, especially Computer Science and other aspects of this area that is saw as potentially leading to careers in computing, but also use of the computer in other subject areas. In 1985, as part of the ACS hosted 'First Pan-Pacific Computer Conference (PPCC-1)', we ran a Schools' Congress [35] that attracted several hundred senior secondary students to listen to a series of speakers discussing issues including: movie making with computers, computing careers, computers in business, videotext in education, robots, communications, artificial intelligence and logic programming, computer science, magnetic storage media and computers in the sciences. Two years later, as part of The Australian Computer Conference (ACC-87) we again ran a Schools' Congress [36]. Topics this time included: expert systems, desktop publishing, computers and music, systems life cycle, computer animation, banking, business, manufacturing, the future of technology in Australia, Electronic Funds Transfer, educational computing, careers and robotics.

Following these Congresses, in a 1988 position paper on education [37] the Australian Computer Society stated its view that:

"The ACS sees the need to widen the facilities made available to academic and secondary teaching staff to develop a closer understanding of the changing business and industry sectors."

In addition to these initiatives, for many years the ACS provided speakers at school careers evenings (including people like Peter Juliff) and to discuss computing careers with students and teachers. 


\subsection{Teacher Subject Associations}

The Victorian Curriculum Assessment Board (VCAB) which controlled Year 12 subjects in Victorian schools was never in a position to assist teachers, spending all their available resources in designing and modifying courses and administering examinations. The VCAB Computer Science Course Management Committee likewise did not itself have the resources to assist teachers, except with advice [38]. Clearly, other forms of support were required.

The Computer Education Group of Victoria (CEGV) was originally formed in the late 1970s as an association of teachers, teacher educators and others interested in the use of computers in education. It came into prominence in 1979 when it launched the first national computer education conference in Australia. The CEGV, and its counterparts in other states, have exerted a considerable influence on computer education through professional development activities, annual conferences, journals and the provision of other publications and resources [2]. Another type of group to emerge in the early 1980s was the user group. Victorian Apple Computers in Education (VACE) ${ }^{6}$ was such a group, formed at the grass roots by teachers in 1982 to share knowledge between those using Apple][ computers. At this stage, computer education had not progressed to the stage of being, to any degree, hardware independent. Schools using Apples had little to discuss with those using TRS-80, Acorn BBC, Cromenco or Commodore computers as the software and applications had little in common [2].

In mid-1988, the Year 12 Computer Science Course Management Committee (of which I was a member) met with the Executive of the CEGV to put the view that the CEGV should be more involved in the provision of assistance to teachers of Computer Science, and of the new Information Technology Field of Study. The result was the establishment of the Victorian Information Technology Teachers Association (VITTA), largely through the efforts of Arthur Tatnall and Bill Davey [38]. Many IT teachers appreciated that much 'real computing' was done in a business setting, and that they themselves did not have sufficient knowledge of the way that business operated or what it did. The answer was to arrange a series of monthly evening meetings of VITTA, many of which would involve site visits. The program for the first half of 1989 was as follows:

- February: Kambrook factory - process-control technology and computerassisted management.

- March: Discussion session of the new VCE Information Technology Field of Study.

- April: Hewlett Packard: 'Micros and Mainframes'. Tour of HP's Australian Headquarters and a series of talks on HP's 'New Wave' software, RISC technology and computer peripherals.

- May: Ford Motor Company's Broadmeadows production line: 'Robots and Production'. Tour of the Ford plant with special attention to the use of robots for welding and sub-assembly. Comparison with the other 'human operated' parts of

\footnotetext{
${ }^{6}$ VACE was the successor of Melbourne Apple Computers in Education (MACS), formed in 1981 by Denis Kennedy, Bill Davey and Arthur Tatnall.
} 
the production line. Discussion of the social issues of robots replacing workers, quality control with human workers vs. robots, boredom on a production line and training of workers.

- June: Space Time Research's Supermap CD - use of compact disk optical storage technology.

Later activities included visits to: Australian Airlines avionics centre, Fallshaw Casters - a manufacturing company making considerable use of robotics and Information Technology and Carlton United Breweries to see the use of mainframe computers to run a large business.

In the early 1990s a Year 12 'IT Field of Study' involving three new subjects was introduced to replace Computer Science. Teachers for this field typically came from two quite different backgrounds: former Computer Science teachers, and former commerce / secretarial studies teachers. Finding commonality between these groups was not easy [38].

\section{Conclusion}

This is where these reflections end. After the conclusion of the Commonwealth Computer Education program in 1987 I left the Education Department to take up an Information Systems position in the Faculty of Business at Footscray Institute of Technology, later to become Victoria University. 1991 was the last year of Year 12 Computer Science and the point at which I bowed out of this area. This then was the end of my direct involvement with the school system (but not my interest) except for some work with Lego on evaluation of their Lego Technics kits, two years as President of the CEGV in 1990-1991 and Chairing of the Australian Computers in Education Conference in 1992.

This chapter could have discussed many other computer education innovations and activities in Victoria at this time, but I have restricted it to my own personal experiences. These other activities would have included software issues such as the development of Apple][ software by a couple of teachers at Myrtleford High School and the subsequent establishment of Seasen Software Pty Ltd, educational software created in conjunction with SCEC and developed by Prologic, development of software for school management, use of other software from $\operatorname{MECCS}^{7}$, use of software in science [39], computer games and their use in education, and more. Professional development issues that could have been discussed included SCEC's 'Seeding Pair' in-service education program, the 'lighthouse schools' and the contribution to teacher education of the Graduate Diploma in Computer Education at Melbourne University. Other possible issue for discussion could have been the role of computer hardware and software suppliers, the falling costs and increasing power of microcomputers, the contribution of the ACS, the attempts to involve girls in the use of computers, to assist students with learning disabilities and the development and use of Lego robotics. Much more still needs to be written.

\footnotetext{
${ }^{7}$ Minnesota Educational Computing Consortium.
} 


\section{References}

1. Pearcey, T.: A History of Australian Computing. Chisholm Institute of Technology, Melbourne (1988)

2. Tatnall, A.: The Growth of Educational Computing in Australia. In: Goodson, I.F., Mangan, J.M. (eds.) History, Context, and Qualitative Methods in the Study of Education, pp. 207-248. University of Western Ontario, Canada (1992)

3. Tatnall, A., Davey, W.: Streams in the History of Computer Education in Australia. In: Impagliazzo, J., Lee, J.A.N. (eds.) History of Computing in Education, pp. 83-90. Kluwer Academic Publishers / IFIP, Assinippi Park, Massachusetts (2004)

4. Salvas, A.D.: Personal communication, Melbourne (1985)

5. Monash Computing Museum. MONECS Deamon Educational Computer system (2003), http: / / www . csse.monash. edu. au/museum/ (February 2004)

6. Plato Learning. History of Plato Learning (February 2004), http://www.plato.com/aboutus/company_history.asp

7. Davey, W.: Personal communication (1985)

8. Tatnall, A., Davey, W.: Early Computer Awareness Courses in Australian Secondary Schools: Curricula from the late 1970s and early 1980s. In: Impagliazzo, J. (ed.) History of Computing and Education 2. IFIP, vol. 215, pp. 107-116. Springer, Boston (2006)

9. Tatnall, A., Davey, W.: Improving the Chances of Getting your IT Curriculum Innovation Successfully Adopted by the Application of an Ecological Approach to Innovation. Informing Science 7(1), 87-103 (2004)

10. Montgomery, A.Y.: Computers and Society: Teaching Computer Awareness. In: Computer Awareness Conference Papers 1980 Secondary Computer Education Committee. Victorian Commercial Teachers' Association Melbourne (1980)

11. Secondary Computer Education Committee, Year 10 Computer Education: Guidelines for Secondary Schools. Education Department of Victoria, Melbourne (1980)

12. Victorian Institute of Secondary Education, New Computer Science Course. VISE, Melbourne (1980)

13. Victorian Institute of Secondary Education, Computer Science (Group 1), in Higher School Certificate Course Description. VISE, Melbourne (1980)

14. Tatnall, A.: A Logic Error is a Misunderstanding Between the Programmer and the Computer. COM3 Journal 16(1), 15-17 (1990)

15. Tatnall, A., Davey, B.: The Life and Growth of Year 12 Computing in Victoria: An Ecological Model. In: Tatnall, A. (ed.) HC 2010. IFIP AICT, vol. 325, pp. 124-133. Springer, Heidelberg (2010)

16. Victorian Institute of Secondary Education, Computer Science, a Course for the Eighties, in VISE News. VISE, Melbourne (1984)

17. Davey, W.: 1991 VCE (HSC) Computer Science Information and Examples, Melbourne (1991)

18. Victorian Curriculum Assessment Board, Computer Science (Group 1). VACB, Melbourne (1990)

19. Tatnall, A.: Computer Science: New Curricula at the Senior Secondary Level. In: CEGV 1985. Computer Education Group of Victoria, Melbourne (1985)

20. Davey, W., Tatnall, A.: Computer Science; Year 11. In: Salvas, A.D. (ed.) Computing and Education - 1984 and Beyond. CEGV, Melbourne (1984)

21. Tatnall, A.: Watsonia High School: Computer Studies, Year 11. Watsonia High School (1981) 
22. Tatnall, A.: Lowlev for Windows - an Introduction to Low Level Programming. Data Publishing, Melbourne (1995)

23. Tatnall, A., Davey, W.: Computer Science for Year 11. Jacaranda Press, Brisbane (1985)

24. McDougall, A.: Computers and Post-Primary Education in Victoria: a Study of Needs. Education Department of Victoria, Computer Policy Committee, Melbourne (1980)

25. Tatnall, A., Davey, W.: Computer Education Support Structures in Victorian Schools in the 1980s. In: Impagliazzo, J. (ed.) History of Computing and Education 3. IFIP, vol. 269, pp. 1-22. Springer, Boston (2008)

26. Commonwealth Schools Commission, Teaching, Learning and Computers. Report of the National Advisory Committee on Computers in Schools. Commonwealth Schools Commission, Canberra (1983)

27. Tatnall, A.: The Australian Educational Computer That Never Was. IEEE Annals of the History of Computing 35(1), 35-47 (2013)

28. Tatnall, A.: Computers and Science Teaching. Lab Talk 24(4), 5-6 (1980)

29. Tatnall, A., Neville, L.: Artificial Education and Education: a new direction or more of the same tired old thing. In: Australian Computer Education Conference - Tomorrow's Technology Today. CEGV, Adelaide (1987)

30. Tatnall, A., Tatnall, B.: Logo in Control: Control Technology in Education. In: Australian Computer Education Conference - Tomorrow's Technology Today. CEGV, Adelaide (1987)

31. Commonwealth Schools Commission, Teaching, Learning and Computers. 1984 Information Kit. Commonwealth Schools Commission, Canberra (1984)

32. Ministry of Education Victoria, Educational Computing System Specifications 1986. State Computer Education Centre, Melbourne (1986)

33. Commonwealth Schools Commission, Australian School Computer Systems: Educational User Requirements. Commonwealth Schools Commission, Canberra (1986)

34. Commonwealth Schools Commission, Australian School Computer Systems: Technical Requirements. Commonwealth Schools Commission, Canberra (1986)

35. Tatnall, A. (ed.): The First Pan Pacific Computer Conference - Schools' Congress, PPCC1. Australian Computer Society, Melbourne (1985)

36. Tatnall, A. (ed.): The Australian Computer Conference - Schools' Congress, ACC 1987. Australian Computer Society, Melbourne (1987)

37. Australian Computer Society, Position Paper Number 6, 'Education'. Australian Computer Society, Sydney (1998)

38. Tatnall, A., Davey, W.: Making Information Technology Real. In: ACEC 1989 - Backup the Future. CEGACT, Canberra (1989)

39. Tatnall, A.: Fibre Optics, Breakfast Cereal and Computer Science. COM3 Journal 18(1), 6-8 (1991) 